Article

\title{
Understanding the Impact of ESG Practices in Corporate Finance
}

\author{
Sang Kim ${ }^{1}$ and Zhichuan (Frank) $\mathrm{Li}^{2, *}$ \\ 1 Economics Department, Western University, London, ON N6A 3K7, Canada; skim685@uwo.ca \\ 2 Ivey Business School, Western University, London, ON N6A 3K7, Canada \\ * Correspondence: fli@ivey.ca; Tel.: 519-661-4112
}

Citation: Kim, S.; Li, Z.(F.)

Understanding the Impact of ESG Practices in Corporate Finance.

Sustainability 2021, 13, 3746.

https://doi.org/10.3390/su13073746

Academic Editor: Klaus Reiner Schenk-Hoppé

Received: 26 February 2021

Accepted: 21 March 2021

Published: 27 March 2021

Publisher's Note: MDPI stays neutral with regard to jurisdictional claims in published maps and institutional affiliations.

Copyright: (c) 2021 by the authors. Licensee MDPI, Basel, Switzerland. This article is an open access article distributed under the terms and conditions of the Creative Commons Attribution (CC BY) license (https:// creativecommons.org/licenses/by/ $4.0 /)$.

\begin{abstract}
This study examines the relationship between environmental, social, and governance (ESG) factors and corporate financial performance. Specifically, we study various individual ESG categories, both ESG strengths and concerns, and aggregate ESG factor and their impact on corporate financial performance including profitability and financial risk. We find a positive effect of ESG factors on corporate profitability, and the effect is more pronounced for larger firms. Among different ESG categories, corporate governance has the most significant impact, particularly for firms with weak governance. We also find that ESG variables generally have a positive influence on credit rating. In particular, the social factor has the most significant impact on credit rating, while environmental score surprisingly has a negative effect. Overall, this research provides a rationale for ESG integration in the context of investment management and portfolio construction to maximize value and minimize risk.
\end{abstract}

Keywords: corporate financial performance; corporate governance; ESG; credit ratings; ESG investing; risk management

\section{Introduction}

This work explores the relationship between environmental, social, and governance (ESG) factors and corporate financial performance and provides the rationale for ESGintegrated investment management strategies. According to the Financial Times [1], ESG is a term commonly used by investors to assess corporate activities related to environmental, social, and governance areas. ESG factors are also considered non-financial performance indicators and are used to identify issues related to business ethics, corporate social responsibility, and corporate governance.

One of the key ESG investment concepts is ESG integration. According to the United Nations Principles for Responsible Investing [2], ESG integration is defined as "the explicit and systematic inclusion of ESG issues in investment analysis and investment decisions." In other words, ESG integration is the application of ESG factors to the traditional fundamental analysis in the context of investment management.

The notion of ESG or ESG factors has become a key consideration for institutional investors and individual investors. Recently, a growing number of companies have demonstrated a greater commitment to ESG activities in order to be recognized as socially responsible. At the same time, a greater number of asset managers, pension funds and institutional investors have started to assess ESG activities of companies when determining investment decisions. In both academic and professional environments, there is extensive evidence that investors are becoming aware of the ESG and corporate finance relationship. In a recent survey conducted by RBC Global Asset Management [3], approximately $72 \%$ of the respondents incorporate ESG principles into their investment approaches and decision-making processes. Ninety percent of the respondents believe that ESG-integrated portfolios are likely to outperform the market and non-ESG-integrated portfolios. Some of the institutional respondents believe there are potential challenges associated with ESG assessment and disclosure. 
Some studies have examined the potential differences in ESG practices across different regions. For instance, Garcia, Mendes-Da-Silva, and Orsato [4] conducted empirical research to understand the ESG and corporate financial performance relationship in BRICS (Brazil, Russia, China, India and South Africa). ESG is not only popular in developed economies, but ESG consideration also has strong implications in the emerging economies' capital markets. Many studies, including the study conducted by Friede, Busch, and Bassen [5], highlight that ESG investing has created positive outcomes for returns in emerging markets.

Based on the risk-return tradeoff, a fundamental principle of finance, the current literature focusing on return only is misleading. One exception is Clark, Feiner, and Viehs [6] who show that corporate sustainability standards can be a crucial factor in lowering the cost of capital, which comprises cost of debt (i.e., credit score/risk) and cost of equity. We further study and shed light on whether ESG impacts both return and risk and whether the impact is symmetrical across different dimensions such as ESG category, strength and weakness, and firm size.

We find a positive effect of ESG factors on corporate profitability, and the effect is more pronounced for larger firms. Among different ESG categories, corporate governance has the most significant impact, particularly for firms with weak governance. We also find that ESG variables generally have a positive influence on credit rating. In particular, the social factor has the most significant impact on credit rating, while environmental score surprisingly has a negative effect. Overall, the main goal of the research is not to determine which companies to invest in but provide a rationale for ESG integration in the context of investment management and portfolio construction to maximize value and minimize risk.

The paper proceeds as follows. In the next section, we review the literature on the ESG and corporate finance relationship and develop our hypotheses. Section 3 covers data sources, data extraction, the ESG scoring mechanism, and multivariate regression models, while our results are discussed in Section 4 . Section 5 concludes.

\section{Literature Review and Hypothesis Development}

Prior to this research, various types of empirical studies have examined the impact of ESG factors on corporate finance and investment management.

First, there is evidence to support the positive relationship between ESG and positive investment performance. For instance, Derwall, Guenster, Bauer, and Koedijk [7] found that portfolios with a higher eco-efficiency score provide better investment returns. According to Friede, Busch, and Bassen [5], there were about 2200 individual studies from 1970 to 2015. They identified a drastic increase in ESG studies since 2000. To make a generalized conclusion about the relationship between ESG and corporate finance, they aggregated the test results of empirical studies over four decades while understanding the impact of ESG investing in global capital markets. The research in this area is extensive, accelerating, and still inconclusive depending on data sample, sample period, empirical methods, and different industries or countries (e.g., [8-12]). Among these 2200 studies, approximately $90 \%$ of them indicate non-negative relationships between ESG and financial performance variables, while most report the positive impact of ESG factors on corporate financial performance. Most importantly, they found that the positive relationship between ESG and corporate finance performance is stable over time. Based on these results, the following hypothesis was created:

Hypothesis 1: ESG has a positive impact on corporate profitability.

In terms of specific ESG components, Gompers, Ishii, and Metrick [13] exclusively researched the impact of corporate governance. Notably, they researched the relationship between corporate governance and corporate finance areas including enterprise value, profitability, sales, fixed asset purchases, and mergers and acquisitions (M\&A). Using their unique governance index method to estimate shareholders' rights, they concluded that firms with higher index value showed higher firm value, higher level of profits, higher 
sales growth rate, and lower capital expenditure spending, while making a smaller number of corporate acquisitions. The empirical research conducted by Wang and Sarkis [14] concluded that whether companies implement corporate social responsibility (CSR) and corporate governance successfully to generate good CSR outcomes positively impacts their financial performance. CSR practice plays a significant role in corporate finance due to the growing awareness of consumers and investors. Reverte, Gomez-Melero, and CegarraNavarro [15] found a direct positive impact of CSR practice on organization performance across various categories of companies. To better understand the impact of specific ESG components, the following hypothesis was created:

Hypothesis 2: Among different ESG factors, governance category has the most significant impact on corporate finance performance.

Throughout the literature review, it is possible to identify that most of the available literature focuses on the positive impact of ESG factors on either equity prices or profitability of companies. However, it is also arguable that ESG factors can explain uncertainties and other forms of financial risk. For instance, in the empirical research conducted by Kruger [16], there was evidence of the adverse impact of negative CSR events on shareholders' value, which was expressed in cumulative abnormal returns. Albuquerque, Koskinen, and Zhang [17] found that CSR factor decreases systematic risk and improves firm value.

The studies analyzing the relationship between ESG factors and financial risk are more prevalent in professional investment service industries. The United Nations Principles for Responsible Investment (UNPRI) [18] reports that many investors and credit rating agencies consider ESG factors in their credit risk analysis framework. According to their survey, more than 100 institutional investors and nine credit rating agencies are committed to incorporating ESG factors into existing credit risk and credit rating assessments. In the report, the case study of Pacific Investment Management Corporation (PIMCO) shows how incorporating ESG criteria into their sovereign rating analysis can potentially provide more insight into the creditworthiness of sovereign states. In academia, Attig, Ghoul, Guedhami, and Suh [19] found that CSR strengths and concerns affect the credit rating of companies. The CSR components including community relations, diversity, employee relations, and product characteristics have a significant relationship in explaining creditworthiness of companies. Moreover, Stellner, Klein, and Zwergel [20] found a relationship between corporate bond spreads and corporate social performance in Eurozone areas. To examine the ESG and financial risk relationship, the following hypothesis was constructed:

Hypothesis 3: ESG factors have a significant correlation with corporate credit risks, which are measured by credit ratings.

\section{Data and Analysis}

This section covers the data collection process and the overall research method.

\subsection{Data Collection and Variable Construction}

To create sample datasets, corporate financial datasets were extracted from S\&P Capital IQ-Compustat database. It covers 172,437 observations from 1991 to 2013 based on 4708 firms in all industries. The Compustat database contains financial and statistical information. Table 1 shows the variables that are extracted to perform multivariate regression analyses: 
Table 1. Selected corporate finance and environmental, social, and governance (ESG) variables.

\begin{tabular}{ll}
\hline & Variables \\
\hline Size measure & Total assets \\
\hline Investment & Invested capital \\
\hline Capital structure & Total liabilities, stockholders' equity \\
\hline Profitability & Earnings before interest and taxes (EBIT), net income \\
\hline Taxes and interests & Total income taxes, total interest and related expense \\
\hline Credit risk & S\&P long-term issuer credit rating (SPLTICRM) \\
\hline
\end{tabular}

Prior to performing an ESG scoring process, two sample datasets were created. The first sample was created by combining the Compustat dataset and the MSCI ESG dataset. Throughout the sample construction process, since the database contains investment fund information, the observations with missing total assets, earnings before interest and taxes (EBIT), and net income values were removed. Although some researchers such as Lins, Servaes, and Tamayo [21] removed the observations with low market capitalization below $\$ 250$ million due to liquidity issues, this paper includes all the observations. The main reason for this approach is to derive a generalized conclusion about the ESG and corporate financial performance relationship for various types of companies.

For ESG factors, the MSCI ESG Stats database was used to extract the ESG information of companies from 1991 to 2013. Please see Table 2 for ESG variables and number of observations. The database contains environmental, social, and governance scores of publicly traded companies. The ESG ratings are recorded on an annual basis. Therefore, all financial information used for the analyses was on an annual basis. Using the information available on the database, new sets of ESG scores were calculated. Raw environmental, social, and governance scores were assigned with their quantile values as new ESG scores. In Table 3, the scoring-system-based quantile approach is outlined. For instance, if there is an observation with an MSCI environmental strength score of 5, the observation has 0.857143 as a new score. The strongest MSCI score observations had a score of 1 . Each MSCI score can be considered a group, range, or quantile, and the observation's new score is the maximum value for the corresponding quantile range (e.g., MSCI 5 for environmental strength ranges from 0.857143 to 0.714286 ). One of the most notable issues of using raw ESG score is derived from observations with identical ESG scores. For instance, using raw scores can create observations with ESG scores of 0 (for all three ESG areas). Although some observations may have different values for the selected financial performance indicators, it is possible to identify other observations with identical ESG scores. In other words, using raw scores might not effectively explain ESG and corporate financial performance relationships with identical scores but with different financial performance indicators. To overcome the measurement issue, each observation with ESG scores was assigned a quantile value. Table 3 describes the quantile scales for corresponding ESG scores. The total ESG composite scores were calculated using an average of three ESG quantile scores. Certain variables were not used to provide a more objective perspective. The MSCI ESG database also contains the ratings for alcohol, arms sales, gambling, nuclear, military, and tobacco. However, the relevance of these categories is questionable since they are only applicable to certain industries and/or companies in the database.

Table 4 provides formulas and data sources for the dependent variable and control variables we use in our study; Table 5 shows formulas, and data sources for the ESG variables. Lastly, the credit rating information and S\&P long-term issuer credit ratings were extracted from the Compustat database and matched to the first research sample. Please refer to Table 6 for more details. 
Table 2. ESG variables and number of observations.

\begin{tabular}{|c|c|c|c|c|c|c|c|c|c|c|c|c|c|c|}
\hline \multirow{3}{*}{$\begin{array}{c}\text { Observation } \\
\text { MSCI } \\
\text { Score }\end{array}$} & \multirow{2}{*}{\multicolumn{2}{|c|}{$\begin{array}{c}\text { Environmental } \\
\text { Environment }\end{array}$}} & \multicolumn{10}{|c|}{ Social } & \multicolumn{2}{|c|}{ Governance } \\
\hline & & & \multicolumn{2}{|c|}{ Community } & \multicolumn{2}{|c|}{ Diversity } & \multicolumn{2}{|c|}{ Employee Relations } & \multicolumn{2}{|c|}{ Human Rights } & \multicolumn{2}{|c|}{ Product } & \multicolumn{2}{|c|}{ Corporate Governance } \\
\hline & Strengths & Concerns & Strengths & Concerns & Strengths & Concerns & Strengths & Concerns & Strengths & Concerns & Strengths & Concerns & Strengths & Concerns \\
\hline 0 & 32,512 & 33,987 & 34,296 & 35,895 & 27,681 & 22,868 & 29,639 & 27,821 & 37,752 & 36,806 & 35,414 & 32,625 & 32,971 & 26,268 \\
\hline 1 & 3786 & 2701 & 3076 & 2416 & 6308 & 12,191 & 5575 & 8629 & 471 & 1520 & 2841 & 4305 & 5287 & 10,859 \\
\hline 2 & 1185 & 1078 & 790 & 135 & 2483 & 3382 & 1754 & 1684 & 227 & 116 & 190 & 1118 & 181 & 1177 \\
\hline 3 & 604 & 449 & 220 & 4 & 1159 & 9 & 655 & 277 & & 8 & 5 & 351 & 11 & 134 \\
\hline 4 & 294 & 190 & 62 & & 471 & & 442 & 37 & & & & 51 & & 12 \\
\hline 5 & 67 & 45 & 6 & & 220 & & 234 & 2 & & & & & & \\
\hline 6 & 2 & & & & 104 & & 91 & & & & & & & \\
\hline 7 & & & & & 24 & & 45 & & & & & & & \\
\hline 8 & & & & & & & 13 & & & & & & & \\
\hline 9 & & & & & & & 2 & & & & & & & \\
\hline 10 & & & & & & & & & & & & & & \\
\hline
\end{tabular}

Table 3. ESG variables and scoring system.

\begin{tabular}{|c|c|c|c|c|c|c|c|c|c|c|c|c|c|c|}
\hline \multirow{3}{*}{$\begin{array}{c}\text { Quantile- } \\
\begin{array}{c}\text { Based } \\
\text { Score }\end{array} \\
\begin{array}{l}\text { MSCI } \\
\text { Score }\end{array}\end{array}$} & \multirow{2}{*}{\multicolumn{2}{|c|}{$\begin{array}{c}\text { Environmental } \\
\text { Environment }\end{array}$}} & \multicolumn{10}{|c|}{ Social } & \multicolumn{2}{|c|}{ Governance } \\
\hline & & & \multicolumn{2}{|c|}{ Community } & \multicolumn{2}{|c|}{ Diversity } & \multicolumn{2}{|c|}{ Employee Relations } & \multicolumn{2}{|c|}{ Human Rights } & \multicolumn{2}{|c|}{ Product } & \multicolumn{2}{|c|}{ Corporate Governance } \\
\hline & Strengths & Concerns & Strengths & Concerns & Strengths & Concerns & Strengths & Concerns & Strengths & Concerns & Strengths & Concerns & Strengths & Concerns \\
\hline 0 & 0.142857 & 1 & 0.166667 & 1 & 0.125 & 1 & 0.1 & 1 & 0.333333 & 1 & 0.25 & 1 & 0.25 & 1 \\
\hline 1 & 0.285714 & 0.833333 & 0.333333 & 0.75 & 0.25 & 0.75 & 0.2 & 0.833333 & 0.666667 & 0.75 & 0.5 & 0.8 & 0.5 & 0.8 \\
\hline 2 & 0.428571 & 0.666667 & 0.5 & 0.5 & 0.375 & 0.5 & 0.3 & 0.666667 & 1 & 0.5 & 0.75 & 0.6 & 0.75 & 0.6 \\
\hline 3 & 0.571429 & 0.5 & 0.666667 & 0.25 & 0.5 & 0.25 & 0.4 & 0.5 & 1 & 0.25 & 1 & 0.4 & 1 & 0.4 \\
\hline 4 & 0.714286 & 0.333333 & 0.833333 & & 0.625 & & 0.5 & 0.333333 & & & & 0.2 & & 0.2 \\
\hline 5 & 0.857143 & 0.166667 & 1 & & 0.75 & & 0.6 & 0.166667 & & & & & & \\
\hline 6 & 1 & & & & 0.875 & & 0.7 & & & & & & & \\
\hline 7 & & & & & 1 & & 0.8 & & & & & & & \\
\hline 8 & & & & & & & 0.9 & & & & & & & \\
\hline 9 & & & & & & & 1 & & & & & & & \\
\hline 10 & & & & & & & & & & & & & & \\
\hline
\end{tabular}

Table 4. Variables, formulas, and data sources.

\begin{tabular}{|c|c|c|c|c|}
\hline Category & Type & Measure & Formula & Source \\
\hline \multirow{2}{*}{ Dependent variable } & \multirow{2}{*}{ Financial performance } & Return on Assets & $\frac{\text { Net Income }}{\text { Total Asset }}$ & $\begin{array}{l}\text { Compustat-Capital IQ } \\
\text { (Annual Fundamentals) }\end{array}$ \\
\hline & & $\begin{array}{l}\text { Customized credit rating } \\
\text { scale (assigned with numeric } \\
\text { values for each rating) }\end{array}$ & $\begin{array}{l}\text { S\&P domestic long term } \\
\text { issuer credit rating }\end{array}$ & $\begin{array}{c}\text { Compustat-Capital IQ } \\
\text { (Daily Updates-Ratings) }\end{array}$ \\
\hline \multirow{8}{*}{$\begin{array}{l}\text { Control/independent } \\
\text { variables }\end{array}$} & \multirow{4}{*}{ ESG } & Total ESG score & \multirow{4}{*}{$\begin{array}{l}\text { Please refer to Table } 5 \text { for } \\
\text { more details }\end{array}$} & \multirow{4}{*}{ MSCI ESG KLD } \\
\hline & & Environmental score & & \\
\hline & & Social score & & \\
\hline & & Governance score & & \\
\hline & Leverage & Debt-to-equity & $\frac{\text { Total liabilities }}{\text { Shareholders }^{\prime} \text { Equity }}$ & \multirow{4}{*}{$\begin{array}{l}\text { Compustat-Capital IQ } \\
\text { (Annual Fundamentals) }\end{array}$} \\
\hline & Liquidity & Interest coverage ratio & $\frac{E B I T}{\text { Interest Expense }}$ & \\
\hline & Size & Total assets & Ln (Total Asset) & \\
\hline & Investment & Return on invested capital & $\frac{\text { EBIT-Income Tax }}{\text { Invested Capital }}$ & \\
\hline
\end{tabular}

Table 5. Variables, formulas, and data sources.

\begin{tabular}{ccc}
\hline ESG component & Variables & Formula \\
\hline Environmental & Environmental strength and concerns & $\sum$ (Environmental strength + Environemntal concerns) \\
\hline Social & $\begin{array}{c}\text { Social strengths and concerns (i.e., community, human rights, } \\
\text { employment, diversity, product) }\end{array}$ & $\begin{array}{c}\sum \text { (Community, human rights, empoyment, diversity and product strengths }+ \\
\text { Community, human rights, empoyment, diversity and productconcerns) }\end{array}$ \\
\hline Governance & Corporate governance strength and concerns & $\sum$ (Corporate governance strengths + Corporate governance concerns) \\
\hline Total ESG score & Average environmental, social, and governance scores & Average of the new environmental, social, and governance scores \\
\hline
\end{tabular}


Table 6. Credit ratings and rating scores.

\begin{tabular}{cc}
\hline Rating & Score \\
\hline AAA & 24 \\
AA+ & 23 \\
AA & 22 \\
AA- & 21 \\
A+ & 20 \\
A & 19 \\
A- & 18 \\
BBB+ & 17 \\
BBB & 16 \\
BBB- & 15 \\
BB+ & 14 \\
BB & 13 \\
BB- & 12 \\
B+ & 11 \\
B & 10 \\
B- & 9 \\
CCC+ & 8 \\
CCC & 7 \\
CCC- & 6 \\
CC+ & CC \\
CC- & 5 \\
C & 4 \\
D & 3 \\
& 2 \\
\hline
\end{tabular}

\subsection{Research Method}

Throughout the analyses, firm fixed effect and time fixed effect were applied to deal with endogeneity issues. Natural log was applied to total asset observations to mitigate potential issues related to measurement and measurement scaling.

For the preliminary regression analysis, eight multivariate regression models were constructed: four regressions for the profitability variable (i.e., Return on Assets, ROA) and four regressions for the credit risk variable (i.e., credit rating). Furthermore, the sample dataset was categorized by asset size and total ESG score for further analysis. The main reason for this in-depth analysis process is to identify potential patterns in the sample dataset while gaining a better understanding of the ESG and corporate financial performance relationship in specific settings. The following are the generalized regression formulas that were used throughout the research:

$$
\begin{aligned}
& \text { RoA } \left.=\alpha+\beta_{1} \text { (Environmental score, Social score, Governance score, or Total ESG score } e_{i, t}\right) \\
& +\beta_{2}\left({\text { Debt } \left./ \text { Equity ratio }_{i, t}\right)}\right) \beta_{3}\left(\text { Liquidity }_{i, t}\right)+\beta_{4}\left(\ln (\text { total asset })_{i, t}\right)+\beta_{5}\left(\text { ROIC }_{i, t}\right)
\end{aligned}
$$

\section{Findings}

\subsection{Preliminary Analysis}

\subsubsection{Descriptive Statistics}

Each ESG component and aggregate ESG score was assessed. Table 7 describes the summary statistics of the variables used to examine the first and second hypotheses, and Table 8 describes the summary statistics for the variables used to examine the ESG and credit rating relationship. 
Table 7. Descriptive statistics for ESG and ROA sample.

\begin{tabular}{|c|c|c|c|c|c|c|c|c|}
\hline & Number of obs. & Mean & Median & SD & Skewness & Kurtosis & $\begin{array}{l}\text { First Quartile } \\
\qquad(25 \%)\end{array}$ & $\begin{array}{c}\text { Third Quartile } \\
(75 \%)\end{array}$ \\
\hline ROA & 21,341 & 0.0257 & 0.0409 & 0.1562 & -7.2674 & 143.0632 & 0.0100 & 0.0783 \\
\hline Debt/Equity & 21,341 & 2.4750 & 1.1643 & 59.1259 & 46.5286 & 3828.2280 & 0.6011 & 2.1738 \\
\hline Liquidity & 21,341 & 93.3497 & 5.7615 & 1778.3202 & 31.8462 & 1807.1002 & 1.9979 & 16.8703 \\
\hline Ln(asset) & 21,341 & 7.4543 & 7.3156 & 1.6933 & 0.4788 & 0.3457 & 6.2600 & 8.4700 \\
\hline ROIC & 21,341 & 0.0747 & 0.0932 & 1.9128 & -125.6928 & 17315.5472 & 0.0522 & 0.1424 \\
\hline Environment & 21,341 & 0.5705 & 0.5714 & 0.0631 & -0.4206 & 8.7492 & 0.5714 & 0.5714 \\
\hline Social & 21,341 & 0.5861 & 0.5825 & 0.0338 & 0.4867 & 2.0187 & 0.5683 & 0.6000 \\
\hline Governance & 21,341 & 0.6031 & 0.6250 & 0.0738 & 0.0090 & 1.0532 & 0.5250 & 0.6250 \\
\hline Total ESG & 21,341 & 0.5866 & 0.5896 & 0.0381 & 0.0675 & 3.4128 & 0.5646 & 0.6013 \\
\hline
\end{tabular}

Table 8. Descriptive statistics for ESG and credit ratings sample.

\begin{tabular}{|c|c|c|c|c|c|c|c|c|}
\hline & \# of obs. & Mean & Median & SD & Skewness & Kurtosis & $\begin{array}{l}\text { First Quartile } \\
(25 \%)\end{array}$ & $\begin{array}{c}\text { Third Quartile } \\
(75 \%)\end{array}$ \\
\hline Rate & 10,619 & 15.0742 & 15.0000 & 3.3155 & 0.0691 & -0.2079 & 12.0000 & 17.0000 \\
\hline Debt/Equity & 10,619 & 3.6020 & 1.6275 & 82.4827 & 34.1130 & 2024.1257 & 1.0125 & 2.7814 \\
\hline Liquidity & 10,619 & 15.1653 & 4.5754 & 281.9472 & 67.9201 & 5112.4644 & 2.1104 & 10.2205 \\
\hline Ln(asset) & 10,619 & 8.5093 & 8.3230 & 1.4433 & 0.6385 & 0.5318 & 7.5100 & 9.4200 \\
\hline ROIC & 10,619 & 0.0864 & 0.0994 & 2.5826 & -101.8029 & $10,448.3578$ & 0.0649 & 0.1476 \\
\hline Environment & 10,619 & 0.5676 & 0.5714 & 0.0823 & -0.3405 & 4.3992 & 0.5714 & 0.5714 \\
\hline Social & 10,619 & 0.5898 & 0.5900 & 0.0390 & 0.3499 & 1.5139 & 0.5708 & 0.6100 \\
\hline Governance & 10,619 & 0.5921 & 0.6250 & 0.0768 & -0.0235 & 1.1172 & 0.5250 & 0.6250 \\
\hline Total ESG & 10,619 & 0.5832 & 0.5869 & 0.0454 & 0.1541 & 2.5392 & 0.5588 & 0.6021 \\
\hline
\end{tabular}

Table 6 reveals summary statistics for corporate financial performance variables, and most of the variables are accounting-based indicators. Overall, the size of the first research sample is 21,341 . The firm with median characteristics in the sample has ROA of 0.041, Debt over Equity (D/E) ratio of 1.164267, interest coverage ratio of 5.76149, total assets of about $\$ 1.727$ billion, and return on invested capital (ROIC) of approximately $9 \%$. In terms of ESG scores, the median sample firm has an environment score of 0.57 , social score of 0.5825 , governance score 0.625 , and total ESG score of 0.59 . Nevertheless, it is also possible to identify extreme values in certain accounting-based performance measures. For instance, $\mathrm{D} / \mathrm{E}$ ratio, interest coverage ratio, and ROIC have very abnormal distribution.

Table 7 shows the descriptive statistics used to assess the ESG-credit rating relationship. Please note that during the sample data structure for the ESG-credit rating relationship, the number of observations decreased by 10,722 compared to the first dataset, which was used to analyze the ESG-ROA relationship. Due to the availability of data and lack of information disclosure, the number of observations decreased by half. In this sample set, the median firm has a credit rating of 15 or BBB-, D/E ratio of 1.628, interest coverage ratio of 4.58 , total assets of approximately $\$ 4.117$ billion, and ROIC of approximately $10 \%$. In terms of ESG scores, the median firm possesses an environment score of 0.571429, social score of 0.59, governance score of 0.625, and total ESG score of 0.586865 . Based on the initial finding, it is possible to observe potential issues related to the proposed ESG score calculation method. Apart from the environmental score, the ESG scores are somewhat well-distributed (based on their mean, standard deviation, skewness, and kurtosis statistics). However, the environmental scores from both sample sets have very concentrated distribution near the mean/median. In particular, the first and third quantile for the calculated environmental score are identical.

\subsubsection{Correlation Analysis}

Table 9 shows the correlation analysis using the first sample dataset. Overall, it is difficult to find any strong correlations (i.e., 0.7 and above) between variables. In terms of the selected ESG variables, the dependent variable is weakly correlated to the firm profitability measure. The size variable, natural log of total assets size, is significant in terms of correlation. First, the control variable is moderately correlated to the profitability variable 
(0.16719). In terms of ESG variables, social, and governance variables are moderately correlated to the firm size variable (i.e., 0.19 and -0.20 ). Among the ESG variables, the social variable has the strongest correlation with the dependent variable.

Table 9. Correlation analysis for ESG-ROA sample.

\begin{tabular}{|c|c|c|c|c|c|c|c|c|c|}
\hline & ROA & Environment & Social & Governance & Total ESG & Debt/Equity & Interest Coverage & Ln (Asset) & ROIC \\
\hline ROA & 1.000 & & & & & & & & \\
\hline Environment & 0.021 & 1.000 & & & & & & & \\
\hline Social & 0.054 & 0.268 & 1.000 & & & & & & \\
\hline Governance & -0.016 & 0.085 & 0.107 & 1.000 & & & & & \\
\hline Total ESG & 0.017 & 0.687 & 0.513 & 0.725 & 1.000 & & & & \\
\hline Debt/Equity & -0.003 & -0.002 & -0.002 & 0.000 & -0.002 & 1.000 & & & \\
\hline Interest coverage & 0.111 & 0.012 & -0.009 & 0.006 & 0.008 & -0.002 & 1.000 & & \\
\hline Ln (asset) & 0.167 & -0.019 & 0.199 & -0.202 & -0.082 & 0.016 & -0.021 & 1.000 & \\
\hline ROIC & -0.040 & 0.002 & 0.011 & -0.004 & 0.002 & 0.000 & 0.002 & 0.018 & 1.000 \\
\hline
\end{tabular}

In Table 10, the correlation between the custom credit rating variable and the ESG variables are more significant compared to the previous results in Table 9. In particular, the correlation between credit rating rate and social variable is 0.17712 .

Table 10. Correlation analysis for ESG—credit ratings sample.

\begin{tabular}{|c|c|c|c|c|c|c|c|c|c|}
\hline & Rate & Environment & Social & Governance & Total ESG & Debt/Equity & Interest Coverage & Ln (Asset) & ROIC \\
\hline Rate & 1.000 & & & & & & & & \\
\hline Environment & 0.065 & 1.000 & & & & & & & \\
\hline Social & 0.177 & 0.290 & 1.000 & & & & & & \\
\hline Governance & -0.062 & 0.113 & 0.125 & 1.000 & & & & & \\
\hline Total ESG & 0.064 & 0.830 & 0.530 & 0.587 & 1.000 & & & & \\
\hline Debt/Equity & -0.013 & -0.001 & -0.004 & 0.003 & 0.000 & 1.000 & & & \\
\hline Interest coverage & 0.012 & 0.011 & 0.013 & -0.010 & 0.007 & -0.001 & 1.000 & & \\
\hline Ln (asset) & 0.568 & 0.043 & 0.113 & -0.159 & -0.015 & -0.003 & 0.004 & 1.000 & \\
\hline ROIC & 0.037 & 0.003 & 0.011 & -0.004 & 0.003 & 0.000 & -0.003 & 0.013 & 1.000 \\
\hline
\end{tabular}

Based on both correlation results, it is possible to conclude that the ESG variables are barely correlated with other financial measure categories: capital structure, liquidity, and investment. The size variable, natural log of total assets, is correlated with both profitability and credit rating proxy. The relationship between ESG and total assets is further discussed later in the paper.

\subsubsection{Regression Analysis 1: ESG and Profitability}

Table 11 shows the result of the regression analyses using profitability as a dependent variable. Overall, the regression models have somewhat consistent adjusted R-squared values (0.59-0.6 range with RMSE of approximately 0.111$)$. The first regression model using the environment variable as an ESG factor shows that the variable is not significant. It is also possible to identify that some control variables have very low economic significance (i.e., coefficients close to zero). Some findings from the correlation analysis also appear in this analysis phase. The asset size variable, natural log of total assets, is both economically and statistically significant. Similarly, the regression model with the social variable shows that the variable is not significant. The capital structure variable and liquidity variable also have very limited economic significance. The third regression model shows somewhat similar results as Wang and Sarkis [14] concluded in their research. The governance variable in the third model has a coefficient estimate of 0.0291920181 with t-statistics of 2.17 ( $p$-value less than 0.05). 
Table 11. Regression analysis for ESG—profitability sample.

\begin{tabular}{|c|c|c|c|c|}
\hline $\begin{array}{c}\text { Coefficient } \\
\text { (t-Value) }\end{array}$ & $\begin{array}{c}1 \\
\text { (Environment Score) }\end{array}$ & $\begin{array}{c}2 \\
\text { (Social Score) }\end{array}$ & $\begin{array}{c}3 \\
\text { (Governance Score) }\end{array}$ & $\begin{array}{c}4 \\
\text { (Total ESG Score) }\end{array}$ \\
\hline Dependent Variable & \multicolumn{4}{|c|}{ Return on Assets } \\
\hline Environmental & $\begin{array}{c}0.01925888 \\
\quad(1.04)\end{array}$ & & & \\
\hline Social & & $\begin{array}{c}0.0113812236 \\
(0.32)\end{array}$ & & \\
\hline Governance & & & $\begin{array}{l}0.0289211886 \\
(2.17)\end{array}$ & \\
\hline Total & & & & $\begin{array}{l}0.0571147083 \\
(2.09)\end{array}$ \\
\hline Debt/equity ratio & $\begin{array}{c}-0.000022 \\
(-1.61) \\
\end{array}$ & $\begin{array}{c}-0.0000221620 \\
(-1.61)\end{array}$ & $\begin{array}{c}-0.0000220973 \\
(-1.61) \\
\end{array}$ & $\begin{array}{c}-0.0000221420 \\
(-1.6)\end{array}$ \\
\hline $\begin{array}{l}\text { Liquidity (interest } \\
\text { coverage) }\end{array}$ & $\begin{array}{c}0.000003 \\
(6.18)\end{array}$ & $\begin{array}{c}0.0000032846 \\
(6.19)\end{array}$ & $\begin{array}{c}0.0000032752 \\
(6.17)\end{array}$ & $\begin{array}{c}0.0000032766 \\
(6.18)\end{array}$ \\
\hline Ln (total assets) & $\begin{array}{l}0.0133348972 \\
(6.36)\end{array}$ & $\begin{array}{l}0.0135842003 \\
(6.52) \\
\end{array}$ & $\begin{array}{c}0.0138897899 \\
(6.7) \\
\end{array}$ & $\begin{array}{l}0.0134972425 \\
(6.48) \\
\end{array}$ \\
\hline ROIC & $\begin{array}{c}-0.0077770740 \\
(-17.08)\end{array}$ & $\begin{array}{c}-0.0077769496 \\
(-17.50)\end{array}$ & $\begin{array}{c}-0.0077711489 \\
(-17.06)\end{array}$ & $\begin{array}{c}-0.0076574709 \\
(-17.49)\end{array}$ \\
\hline Firm fixed effect & Yes & Yes & Yes & Yes \\
\hline Year fixed effect & Yes & Yes & Yes & Yes \\
\hline Adjusted R-squared & 0.591289 & 0.591265 & 0.591375 & 0.591366 \\
\hline RMSE & 0.111059 & 0.111062 & 0.111047 & 0.111048 \\
\hline
\end{tabular}

Lastly, the total ESG factor variable is also economically and statistically significant. It has a coefficient estimate of about 0.05781 with t-statistics of 2.11 (p-value less than 0.05 ).

Although two of the ESG variables are not statistically significant, the findings from the governance and total ESG factor regression are moderately aligned with the first two hypotheses. The results are generally consistent with the literature.

Notably, the impact of ESG on firm performance is mainly driven by the governance factor. This supplements the literature findings of the positive relationship between ESG or CSR and performance. As Gompers, Ishii, and Metrick [13] argued, effective corporate governance practice can create positive results in the context of corporate financial performance. Larcker, Richardson, and Tuna [22] conclude that corporate governance has a certain ability to explain operating performance and potential stock returns.

\subsubsection{Regression Analysis 4: ESG and Credit Rating}

Dunbar, Li, Shi [23] find CSR reduces risk, moderated by corporate governance. We find further support by studying different categories of ESG and firm credit rating. Table 12 shows the result of the regression analyses using credit rating as a dependent variable. Overall, the regression models have very strong adjusted R-squared values (0.90-0.91 range with RMSE of approximately 1.09). Interestingly, all the ESG factor variables are both economically and statistically significant. Among different ESG variables, it is possible that the social variable is the most significant in explaining credit ratings. The first regression model using the environment variable has an environment coefficient estimate of -0.6042 with $\mathrm{t}$-statistics of -3.04 . The social regression model has the highest coefficient of 2.6856 with t-statistics of 6.24. The governance variable, which is the most significant variable from the previous exercise, is also significant. It has the coefficient estimate of 0.7441 and t-statistics of 4.27. Lastly, the composite ESG score variable has a coefficient of 0.8308 with t-statistics of 2.56. With the exception of the ROIC variable, the accounting variables are not as significant as the previous exercise. 
Table 12. Regression analysis for ESG—credit ratings sample.

\begin{tabular}{|c|c|c|c|c|}
\hline $\begin{array}{l}\text { Coefficient } \\
\text { (t-Value) }\end{array}$ & $\begin{array}{c}1 \\
\text { (Environment Score) }\end{array}$ & $\begin{array}{c}2 \\
\text { (Social Score) }\end{array}$ & $\begin{array}{c}3 \\
\text { (Governance Score) }\end{array}$ & $\begin{array}{c}4 \\
\text { (Total ESG Score) }\end{array}$ \\
\hline Dependent Variable & \multicolumn{4}{|c|}{ Credit ratings } \\
\hline Environmental & $\begin{array}{c}-0.7921599181 \\
(-3.78)\end{array}$ & & & \\
\hline Social & & $\begin{array}{l}3.263782323 \\
\quad(7.20)\end{array}$ & & \\
\hline Governance & & & $\begin{array}{c}0.7760999963 \\
(4.23)\end{array}$ & \\
\hline Total & & & & $\begin{array}{c}0.8103105806 \\
(2.37)\end{array}$ \\
\hline Debt/equity ratio & $\begin{array}{c}0.0000456085 \\
(0.31)\end{array}$ & $\begin{array}{l}0.000036182 \\
(0.25)\end{array}$ & $\begin{array}{c}0.0000480792 \\
(0.33)\end{array}$ & $\begin{array}{c}0.0000466122 \\
(0.32)\end{array}$ \\
\hline $\begin{array}{l}\text { Liquidity (interest } \\
\text { coverage) }\end{array}$ & $\begin{array}{c}0.0000538304 \\
(1.13)\end{array}$ & $\begin{array}{c}0.000064069 \\
(1.34)\end{array}$ & $\begin{array}{c}0.0000556374 \\
(1.17)\end{array}$ & $\begin{array}{c}0.0000578243 \\
(1.21)\end{array}$ \\
\hline Ln (total assets) & $\begin{array}{c}0.1775023853 \\
(5.39)\end{array}$ & $\begin{array}{l}0.141817092 \\
\quad(4.35)\end{array}$ & $\begin{array}{c}0.1578156731 \\
(4.84)\end{array}$ & $\begin{array}{c}0.1505208805 \\
(4.59)\end{array}$ \\
\hline ROIC & $\begin{array}{c}0.0227100926 \\
(4.27)\end{array}$ & $\begin{array}{l}0.022706245 \\
\quad(4.28)\end{array}$ & $\begin{array}{c}0.0226876339 \\
(4.27)\end{array}$ & $\begin{array}{c}0.0227131009 \\
(4.27)\end{array}$ \\
\hline Firm fixed effect & Yes & Yes & Yes & Yes \\
\hline Year fixed effect & Yes & Yes & Yes & Yes \\
\hline Adjusted R-squared & 0.899776 & 0.900202 & 0.899816 & 0.899676 \\
\hline RMSE & 1.15488 & 1.152421 & 1.154646 & 1.155453 \\
\hline
\end{tabular}

The overall effect of ESG on credit ratings is positive, while the most important factor is the social category. The negative effect of the environment factor on rating may be explained by substitute effect; firms with high credit rating neglect or invest less in environmental issues, or vice versa. This finding is strongly aligned with the empirical evidence suggested by Attig [19] with the exception of environmental factor.

\subsection{In-Depth Analysis}

\subsubsection{Regression Analysis: Total ESG Score and Size}

Prior to moving on to different dependent variables, the sample dataset was divided into subsamples according to size and total ESG factor scores to further understand the ESG and corporate financial performance relationship in specific settings. The sample dataset was divided into five asset size groups and five total ESG score groups (i.e., quintile approach). Then, multivariate regression models were created using original control variables and the total ESG score as an ESG factor variable. Table 13 shows the regression results using $5 \times 5$ sample datasets. Although it is difficult to find the pattern, it is arguable that the ESG and corporate financial performance relationship is more evident in the largest asset size quintile. The economic significance for this quintile is stronger than the rest of the groups.

\subsubsection{Regression Analysis 3: Governance Score and Size}

To further understand the explanatory power and impact of the governance variable, the sample dataset was divided into asset size measure and governance score. Due to the governance score calculation method and distribution of the score, it was not possible to attain five quantiles for governance. Therefore, the dataset was divided into two groups: above average and below average. Then, multivariate regression models were created using original control variables and the governance score as an ESG factor variable. Table 14 shows the regression results using $2 \times 5$ sample datasets. At the p-value level of 0.05 , three out of five below average governance groups have governance as a significant variable (at the 0.1 level, four are significant). Unlike the previous $5 \times 5$ regression analysis, the asset size measure has a limited contribution to the assessment of the governance variable. For instance, the largest asset size group has very insignificant governance coefficient estimates. Meanwhile, in other groups with below average governance scores, the governance coefficient estimates are both economically and statistically significant. In 
the second governance group (with below average total score), there is a negative impact on corporate profitability.

Table 13. Split regression analysis for ESG—profitability sample $(5 \times 5$ total ESG).

\begin{tabular}{|c|c|c|c|c|c|c|}
\hline \multirow{2}{*}{\multicolumn{2}{|c|}{$\mathbf{R}^{2}$}} & \multicolumn{5}{|c|}{ Total ESG Score } \\
\hline & & Highest (=0) & High (=1) & Medium (=2) & Low $(=3)$ & Lowest (=4) \\
\hline \multirow{5}{*}{$\begin{array}{c}\text { Size } \\
\ln \text { (total assets) }\end{array}$} & Highest $(=0)$ & 0.75114 & 0.902742 & 0.885207 & 0.781194 & 0.526247 \\
\hline & $\operatorname{High}(=1)$ & 0.869233 & 0.787742 & 0.715492 & 0.691 & 0.603529 \\
\hline & Medium (=2) & 0.887176 & 0.62698 & 0.768715 & 0.564351 & 0.67757 \\
\hline & Low (=3) & 0.780158 & 0.886243 & 0.830328 & 0.786774 & 0.667924 \\
\hline & Lowest (=4) & 0.791453 & 0.904458 & 0.796881 & 0.787387 & 0.889998 \\
\hline \multirow{2}{*}{\multicolumn{2}{|c|}{ Beta }} & \multicolumn{5}{|c|}{ Total ESG Score } \\
\hline & & Highest (=0) & High $(=1)$ & Medium (=2) & Low $(=3)$ & Lowest (=4) \\
\hline \multirow{5}{*}{$\begin{array}{c}\text { Size } \\
\ln \text { (total assets) }\end{array}$} & Highest $(=0)$ & 0.1350124 & 0.87045604 & 2.33045983 & 0.4812803 & 0.04245164 \\
\hline & $\operatorname{High}(=1)$ & 0.01644166 & -2.1898699 & -0.951694 & -0.2989014 & 0.29995364 \\
\hline & Medium (=2) & 0.30530236 & 1.9425061 & 1.7649401 & 0.40971369 & -1.8952604 \\
\hline & Low $(=3)$ & -0.2295688 & -1.5754304 & 0.76355465 & -0.2852724 & 0.23001942 \\
\hline & Lowest (=4) & -0.7302102 & 6.09083165 & -2.1612193 & 5.76890031 & -1.7937121 \\
\hline \multirow{2}{*}{\multicolumn{2}{|c|}{$\begin{array}{c}\text { t-stat } \\
(p-v a l)\end{array}$}} & \multicolumn{5}{|c|}{ Total ESG Score } \\
\hline & & Highest (=0) & High $(=1)$ & Medium (=2) & Low $(=3)$ & Lowest (=4) \\
\hline \multirow{5}{*}{$\begin{array}{c}\text { Size } \\
\ln \text { (total assets) }\end{array}$} & Highest $(=0)$ & $2.93(0.0035)$ & $1.02(0.3101)$ & $2.22(0.0277)$ & $1.51(0.1308)$ & $0.57(0.5709)$ \\
\hline & High $(=1)$ & $0.27(0.7869)$ & $-1.59(0.1129)$ & $-0.98(0.3270)$ & $-0.62(0.5384)$ & $1.93(0.0542)$ \\
\hline & Medium (=2) & $1.15(0.2521)$ & $0.81(0.4158)$ & $1.13(0.2585)$ & $0.44(0.6587)$ & $4.31(<0.0001)$ \\
\hline & Low $(=3)$ & 0.89 (0.3749) & $-0.99(0.3246)$ & $0.48(0.6315)$ & $-0.19(0.8515)$ & $0.26(0.7935)$ \\
\hline & Lowest (=4) & $-0.69(0.4907)$ & $1.61(0.1077)$ & $-0.43(0.67)$ & $1.63(0.1046)$ & $-1.41(0.1614)$ \\
\hline
\end{tabular}

4.2.3. Regression Analysis 5: Total ESG Score and Size for Credit Ratings

To further understand the explanatory power and impact of the social variable in explaining credit ratings, the sample dataset was divided into asset size measure and total ESG score. Due to the social score calculation method and the distribution of the score, it was not possible to attain five quantiles for the social variable. Therefore, the dataset was divided into three groups. Table 15 shows the regression results using $3 \times 3$ sub sample datasets. At the $p$-value level of 0.05 , seven of nine sub-sample groups have the social variable as a significant variable. The analyses using the large firm group sample demonstrate unanimous results. Therefore, it is possible to conclude that social variable is significant when explaining credit ratings, and the impact of the variable is stronger among firms with large assets values.

Table 16 shows the distribution of credit rating observations for each ESG score category. It is possible to identify that the top ESG score category has a higher number of investment-grade credit ratings. 
Table 14. Split regression analysis for ESG—profitability sample $(5 \times 2$ governance score $)$.

\begin{tabular}{|c|c|c|c|}
\hline \multirow{2}{*}{\multicolumn{2}{|c|}{$\mathbf{R}^{2}$}} & \multicolumn{2}{|c|}{ Governance Score } \\
\hline & & Above Average $(=0)$ & Below Average $(=1)$ \\
\hline \multirow{5}{*}{$\begin{array}{c}\text { Size } \\
\ln \text { (total assets) }\end{array}$} & Highest $(=0)$ & 0.708257 & 0.555197 \\
\hline & $\operatorname{High}(=1)$ & 0.654775 & 0.532992 \\
\hline & Medium (=2) & 0.509547 & 0.658058 \\
\hline & Low (=3) & 0.683311 & 0.683472 \\
\hline & Lowest (=4) & 0.725478 & 0.845653 \\
\hline \multirow{2}{*}{\multicolumn{2}{|c|}{ Beta }} & \multicolumn{2}{|c|}{ Governance Score } \\
\hline & & Above Average $(=0)$ & Below Average $(=1)$ \\
\hline \multirow{5}{*}{$\begin{array}{c}\text { Size } \\
\ln \text { (total assets) }\end{array}$} & Highest $(=0)$ & 0.00304542 & -0.003993766 \\
\hline & $\operatorname{High}(=1)$ & 0.020960975 & 0.212051808 \\
\hline & Medium (=2) & -0.012695351 & -0.587320937 \\
\hline & Low $(=3)$ & 0.000021876 & 0.47985045 \\
\hline & Lowest (=4) & 0.045251001 & -1.054522675 \\
\hline \multirow{2}{*}{\multicolumn{2}{|c|}{$\begin{array}{c}\text { t-stat } \\
\text { (p-val) }\end{array}$}} & \multicolumn{2}{|c|}{ Governance Score } \\
\hline & & Above Average $(=0)$ & Below Average $(=1)$ \\
\hline \multirow{5}{*}{$\begin{array}{c}\text { Size } \\
\ln \text { (total assets) }\end{array}$} & Highest $(=0)$ & $0.16(0.8753)$ & $-0.11(0.9095)$ \\
\hline & High (=1) & $0.67(0.5013)$ & $2.69(0.0073)$ \\
\hline & Medium (=2) & $-0.20(0.8401)$ & $-3.81(0.0002)$ \\
\hline & Low $(=3)$ & $0.00(0.9997)$ & $1.61(0.1071)$ \\
\hline & Lowest (=4) & $0.43(0.6671)$ & $-2.01(0.0450)$ \\
\hline
\end{tabular}

Table 15. Split regression analysis for ESG—credit ratings sample $(3 \times 3$ total ESG).

\begin{tabular}{|c|c|c|c|c|}
\hline \multirow{2}{*}{\multicolumn{2}{|c|}{$\mathbf{R}^{2}$}} & \multicolumn{3}{|c|}{ Total ESG Score } \\
\hline & & High $(=0)$ & Medium (=1) & Low $(=2)$ \\
\hline \multirow{3}{*}{$\begin{array}{c}\text { Size } \\
\ln \text { (total assets) }\end{array}$} & Highest $(=0)$ & 0.93564 & 0.926 & 0.90289 \\
\hline & Medium (=1) & 0.914811 & 0.918606 & 0.914881 \\
\hline & Low $(=2)$ & 0.937792 & 0.942719 & 0.940127 \\
\hline \multirow{2}{*}{\multicolumn{2}{|c|}{ Beta }} & \multicolumn{3}{|c|}{ Total ESG Score } \\
\hline & & High $(=0)$ & Medium (=1) & Low $(=2)$ \\
\hline \multirow{3}{*}{$\begin{array}{c}\text { Size } \\
\ln \text { (total assets) }\end{array}$} & Highest $(=0)$ & 3.64371941 & 6.573761057 & 3.026479385 \\
\hline & Medium (=1) & 2.807320519 & 6.441510156 & 4.055975972 \\
\hline & Low $(=2)$ & 10.46045362 & 6.205045382 & 1.952090913 \\
\hline \multirow{2}{*}{\multicolumn{2}{|c|}{$\begin{array}{l}\text { t-stat } \\
\text { (p-val) }\end{array}$}} & \multicolumn{3}{|c|}{ Total ESG Score } \\
\hline & & High $(=0)$ & Medium (=1) & Low $(=2)$ \\
\hline \multirow{3}{*}{$\begin{array}{c}\text { Size } \\
\ln (\text { total assets) }\end{array}$} & Highest $(=0)$ & $\begin{array}{c}3.61 \\
(0.0003)\end{array}$ & $\begin{array}{c}3.26 \\
(0.0012)\end{array}$ & $\begin{array}{c}2.38 \\
(0.0176)\end{array}$ \\
\hline & Medium (=1) & $\begin{array}{c}1.49 \\
(0.1364)\end{array}$ & $\begin{array}{c}2.71 \\
(0.0069)\end{array}$ & $\begin{array}{c}2.02 \\
(0.0441)\end{array}$ \\
\hline & Low $(=2)$ & $\begin{array}{c}4.17 \\
(<0.0001)\end{array}$ & $\begin{array}{c}2.75 \\
(0.0061)\end{array}$ & $\begin{array}{c}0.82 \\
(0.4129)\end{array}$ \\
\hline
\end{tabular}


Table 16. Credit ratings distribution by three total ESG scores.

\begin{tabular}{|c|c|c|c|c|c|c|c|c|}
\hline \multicolumn{3}{|c|}{ High Total ESG } & \multicolumn{3}{|c|}{ Medium Total ESG } & \multicolumn{3}{|c|}{ Low Total ESG } \\
\hline Rating & $\mathbf{n}$ & $\%$ & Rating & $\mathbf{n}$ & $\%$ & Rating & n & $\%$ \\
\hline AAA & 42 & $1.10 \%$ & AAA & 19 & $0.58 \%$ & AAA & 45 & $1.38 \%$ \\
\hline $\mathrm{AA}+$ & 12 & $0.32 \%$ & $\mathrm{AA}+$ & 14 & $0.43 \%$ & $\mathrm{AA}+$ & 7 & $0.21 \%$ \\
\hline AA & 52 & $1.37 \%$ & AA & 41 & $1.25 \%$ & AA & 60 & $1.83 \%$ \\
\hline AA- & 95 & $2.49 \%$ & AA- & 35 & $1.07 \%$ & AA- & 34 & $1.04 \%$ \\
\hline $\mathrm{A}+$ & 210 & $5.51 \%$ & $\mathrm{~A}+$ & 122 & $3.73 \%$ & $\mathrm{~A}+$ & 121 & $3.70 \%$ \\
\hline $\mathrm{A}$ & 344 & $9.03 \%$ & $\mathrm{~A}$ & 231 & $7.06 \%$ & $\mathrm{~A}$ & 279 & $8.53 \%$ \\
\hline A- & 269 & $7.06 \%$ & A- & 214 & $6.54 \%$ & A- & 227 & $6.94 \%$ \\
\hline $\mathrm{BBB}+$ & 409 & $10.74 \%$ & $\mathrm{BBB}+$ & 249 & $7.61 \%$ & $\mathrm{BBB}+$ & 354 & $10.82 \%$ \\
\hline BBB & 556 & $14.60 \%$ & BBB & 483 & $14.77 \%$ & BBB & 560 & $17.12 \%$ \\
\hline BBB- & 426 & $11.18 \%$ & BBB- & 365 & $11.16 \%$ & BBB- & 370 & $11.31 \%$ \\
\hline $\mathrm{BB}+$ & 230 & $6.04 \%$ & $\mathrm{BB}+$ & 201 & $6.14 \%$ & $\mathrm{BB}+$ & 242 & $7.40 \%$ \\
\hline $\mathrm{BB}$ & 278 & $7.30 \%$ & $\mathrm{BB}$ & 282 & $8.62 \%$ & BB & 350 & $10.70 \%$ \\
\hline BB- & 368 & $9.66 \%$ & BB- & 385 & $11.77 \%$ & BB- & 364 & $11.13 \%$ \\
\hline $\mathrm{B}+$ & 268 & $7.04 \%$ & $\mathrm{~B}+$ & 309 & $9.45 \%$ & $\mathrm{~B}+$ & 248 & $7.58 \%$ \\
\hline B & 138 & $3.62 \%$ & B & 212 & $6.48 \%$ & B & 156 & $4.77 \%$ \\
\hline B- & 90 & $2.36 \%$ & B- & 76 & $2.32 \%$ & B- & 90 & $2.75 \%$ \\
\hline $\mathrm{CCC}+$ & 16 & $0.42 \%$ & $\mathrm{CCC}+$ & 19 & $0.58 \%$ & $\mathrm{CCC}+$ & 23 & $0.70 \%$ \\
\hline CCC & 3 & $0.08 \%$ & CCC & 4 & $0.12 \%$ & CCC & 6 & $0.18 \%$ \\
\hline CCC- & 0 & $0.00 \%$ & CCC- & 3 & $0.09 \%$ & CCC- & 0 & $0.00 \%$ \\
\hline $\mathrm{CC}$ & 1 & $0.03 \%$ & $\mathrm{CC}$ & 2 & $0.06 \%$ & $\mathrm{CC}$ & 1 & $0.03 \%$ \\
\hline $\mathrm{D}$ & 0 & $0.00 \%$ & $\mathrm{D}$ & 5 & $0.15 \%$ & $\mathrm{D}$ & 2 & $0.06 \%$ \\
\hline SD & 2 & $0.05 \%$ & SD & 0 & $0.00 \%$ & SD & 0 & $0.00 \%$ \\
\hline Total & 3809 & & Total & 3271 & & Total & 3539 & \\
\hline Investment grade & 2415 & $63.40 \%$ & Investment grade & 1773 & $54.20 \%$ & Investment grade & 2057 & $58.12 \%$ \\
\hline $\begin{array}{l}\text { High-yield/junk } \\
\text { grade }\end{array}$ & 1394 & $36.60 \%$ & $\begin{array}{l}\text { High-yield/junk } \\
\text { grade }\end{array}$ & 1498 & $45.80 \%$ & $\begin{array}{l}\text { High-yield/junk } \\
\text { grade }\end{array}$ & 1482 & $41.88 \%$ \\
\hline
\end{tabular}

Note:Total number of observations $(1991-2013)=10,619$; mean ESG score $=0.5025286$.

\section{Conclusions}

Although it is difficult to generalize the positive impact of ESG factors on corporate finance performance, certain component and aggregate ESG variables positively impact the chosen performance indicators. First and foremost, the total ESG score has a positive impact on corporate profitability. Furthermore, the split regression analyses using the 25 subsample dataset shows the positive impact of ESG factors on corporate profitability for firms with large total assets values. Among different ESG components, corporate governance has the most significant impact on corporate profitability. The positive relationship between governance and corporate profitability was only observed in firms with weak governance. In terms of the relationship between ESG and credit risk, all four ESG factors have a significant impact on credit rating. While social, governance and total ESG score have a positive impact on credit rating, environmental score has a surprisingly negative effect on the credit rating, and social factor has the most significant impact on credit rating.

Overall, the findings of this report prove that ESG factors matter in terms of corporate financial performance and risk. However, the effects vary across different dimensions such as ESG categories, strength and weakness, and firm size. These findings can potentially help investors understand the underpinning rationale for recent trends in ESG-linked or ESG-integrated investment strategies. There are also opportunities for further research. The most important area of improvement is the availability of data and data sources. 
Secondly, there are other market-based dependent variables including stock returns and equity risk. Using equity risk dependent variables will require equity risk models to assign numerical values for each observation or firm. Lastly, applying interaction terms could provide a better understanding of the channels between ESG factors and corporate financial performance variables.

Author Contributions: S.K. conduct data collection and data analysis. S.K. and Z.F.L. co-drafted the manuscript. Z.F.L. provides critical revision. All authors have read and agreed to the published version of the manuscript.

Funding: This research received no external funding.

Institutional Review Board Statement: Not applicable.

Informed Consent Statement: Not applicable.

Data Availability Statement: Data sharing is not applicable to this article.

Conflicts of Interest: The authors declare no conflict of interest.

\section{References}

1. The Financial Times LTD. Definition of ESG. Available online: http://lexicon.ft.com/Term?term=ESG. (accessed on 1 March 2021).

2. The United Nations Principles for Responsible Investment. What Is ESG Integration? Available online: https:/ /www.unpri.org/ investor-tools/what-is-esg-integration/3052.article. (accessed on 1 March 2021).

3. RBC Global Asset Management. Charting a Sustainable Advantage; RBC Global Asset Management: Toronto, ON, Canada, 2018.

4. Garcia, A.S.; Mendes-Da-Silva, W.; Orsato, R.J. Sensitive industries produce better ESG performance: Evidence from emerging markets. J. Clean. Prod. 2017, 150, 135-147. [CrossRef]

5. Friede, G.; Busch, T.; Bassen, A. ESG and financial performance: Aggregated evidence from more than 2000 empirical studies. J. Sustain. Financ. Invest. 2015, 5, 210-233. [CrossRef]

6. Clark, G.L.; Feiner, A.; Viehs, M. From the Stockholder to the Stakeholder: How Sustainability Can Drive Financial Outperformance; Smith School of Enterprise and the Environment, University of Oxford: Oxford, UK, 2015.

7. Derwall, J.; Guenster, N.; Bauer, R.; Koedijk, K. The Eco-Efficiency Premium Puzzle. Financ. Anal. J. 2005, 51-63. [CrossRef]

8. Li, Y.; Gong, M.; Zhang, X.Y.; Koh, L. The impact of environmental, social, and governance disclosure on firm value: The role of CEO power. Br. Account. Rev. 2018, 50, 60-75. [CrossRef]

9. Qureshi, M.A.; Kirkerud, S.; Theresa, K.; Ahsan, T. The impact of sustainability (environmental, social, and governance) disclosure and board diversity on firm value: The moderating role of industry sensitivity. Bus. Strategy Environ. 2020, 29, 1199-1214. [CrossRef]

10. Tamimi, N.; Sebastianelli, R. Transparency among S\&P 500 companies: An analysis of ESG disclosure scores. Manag. Decis. 2017, 55, 1660-1680.

11. Albitar, K.; Hussainey, K.; Kolade, N.; Gerged, A.M. ESG disclosure and firm performance before and after IR. Int. J. Account. Inf. Manag. 2020, 28, 429-444. [CrossRef]

12. Guthrie, J.; Manes Rossi, F.; Orelli, R.L.; Nicolò, G. Investigating risk disclosures in Italian integrated reports. Meditari Account. Res. 2020, 28, 1149-1178. [CrossRef]

13. Gompers, P.A.; Ishii, J.L.; Metrick, A. Corporate Governance and Equity Prices. Q. J. Econ. 2003, 118, 107-155. [CrossRef]

14. Wang, Z.; Sarkis, J. Corporate social responsibility governance, outcomes, and financial performance. J. Clean. Prod. 2017, 162, 1607-1616. [CrossRef]

15. Reverte, C.; Gomez-Melero, E.; Cegarra-Navarro, J.G. The influence of corporate social responsibility practices on organizational performance: Evidence from Eco-Responsible Spanish firms. J. Clean. Prod. 2016, 112, 2870-2884. [CrossRef]

16. Kruger, P. Corporate goodness and shareholder wealth. J. Financ. Econ. 2015, 115, 304-329. [CrossRef]

17. Albuquerque, R.; Koskinen, Y.; Zhang, C. Corporate Social Responsibility and Firm Risk: Theory and Empirical Evidence; European Corporate Governance Institute: Brussels, Belgium, 2017.

18. The United Nations Principles for Responsible Investment (UNPRI). Shifting Perceptions: ESG, Credit Risk and Ratings; The United Nations Principles for Responsible Investment (UNPRI): London, UK, 2017.

19. Attig, N.; Ghoul, S.E.; Guedhami, O.; Suh, J. Corporate Social Responsibility and Credit Ratings. J. Bus. Ethics 2013, 117, 679-694. [CrossRef]

20. Stellner, C.; Klein, C.; Zwergel, B. Corporate social responsibility and Eurozone corporate bonds: The moderating role of country sustainability. J. Bank. Financ. 2015, 59, 538-549. [CrossRef]

21. Lins, K.V.; Servaes, H.; Ane, T. Social Capital, Trust, and Firm Performance: The Value of Corporate Social Responsibility during the Financial Crisis. J. Financ. 2017, 72, 1785-1824. [CrossRef] 
22. Larcker, D.F.; Richardson, S.A.; Tuna, I. Corporate Governance, Accounting Outcomes, and Organizational Performance. Account. Rev. 2007, 82, 963-1008. [CrossRef]

23. Dunbar, C.G.; Li, Z.F.; Shi, Y. Corporate Social (Ir)responsibility and Firm Risk: The Role of Corporate Governance. 2021. Available online: https:/ / ssrn.com/abstract=3791594 (accessed on 1 March 2021). 